\title{
Contemporary Hollywood Crime Film and the New Individualism
}

Luis M. García-Mainar

\section{(2) OpenEdition \\ Journals}

Electronic version

URL: https://journals.openedition.org/ejas/7650

DOI: $10.4000 /$ ejas. 7650

ISSN: 1991-9336

Publisher

European Association for American Studies

Electronic reference

Luis M. García-Mainar, "Contemporary Hollywood Crime Film and the New Individualism", European journal of American studies [Online], 4-2 | 2009, document 4, Online since 04 November 2009, connection on 08 July 2021. URL: http://journals.openedition.org/ejas/7650; DOI: https://doi.org/10.4000/ejas. 7650

This text was automatically generated on 8 July 2021 .

Creative Commons License 


\title{
Contemporary Hollywood Crime Film and the New Individualism ${ }^{1}$
}

\author{
Luis M. García-Mainar
}

Film studies has made Hollywood cinematic genres a fundamental source of scholarly enquiry, genre theory providing the background for discussions of 'categories', from the musical to the war film. The specification of generic conventions is often accompanied by distinct analysis of the film groupings as expressions of social and historical circumstances. The article that follows is set in this area of film studies. Together with the western, the crime film is probably the Hollywood genre most often studied from a social and cultural perspective. From the classic work of Robert Warshow to recent studies by Martin Rubin, Nicole Rafter or Thomas Leitch, critics have argued that crime voices discourses about specific social issues, the conflicting relationship between the individual and social organization taking central ground. Ever since Warshow stated that the gangster embodied the contradiction between democracy and capitalism at the heart of US American society, critical analyses have tended to stress the genre's capacity to reflect the paradoxes that plague the notion of individualism. Books of the late 1970s and early 1980s by Jack Shadoian and Carlos Clarens, or the more recent research by Jonathan Munby, combine historical vocation with a more or less explicit discussion of crime genres as social indicators. Even the more ideological analysis of film noir by J.P. Telotte points out how the genre possesses the specific political agenda to uncover social contradictions. In their search for consistency, these critics have tended to remain faithful to the concept of generic category, at times contributing new definitions, but generally dealing with more or less closed groups of films that represent the main features of each crime genre. This essay proposes to approach genre by looking primarily not into film categories but into cultural discourses in order to then explore the interactions of these discourses with film genres. This approach will not avoid generic categories, the crime film genre will still delimit the scope of the analysis, but that generic consistency will not be emphasised. Rather, emphasis is placed on the way cultural discourses affect conventions that have been associated with the crime film genre, or on how these discourses directly create new conventions. The category of the crime film itself, a 
broad concept in the line of those proposed by Martin Rubin and Thomas Leitch, allows for more flexibility than the discrete classical genres of the gangster film, the suspense thriller, the detective/cop movie, or film noir. The paper will scrutinize the ways in which one contemporary cultural discourse filters into films through already existing generic representations of the crime film, in the process transforming them, at times even introducing new ones, and thus altering the shape and look of recent films about crime.

2 The cultural phenomenon to be discussed here is the renascence of the individual in contemporary industrialized societies. The term New Individualism, recently coined by sociologists Anthony Elliot and Charles Lemert, will be used in order to refer to the individual produced by globalization. According to Alain Touraine, present-day industrialized societies are characterized by the dissolution of the social, that is, the fading of the mechanisms of belonging to groups or institutions such as the community, the workplace, the family or the school. As a result, the social bond breaks down, because individuals no longer share normative meanings within the system. For example, workers refuse to participate in the ideology of corporate success, now replaced by personal success and professionalism: since employees know they can be laid off whenever international corporations decide on costcutting relocations, the labour force concentrate on improving their skills and capacities in order to better compete for future jobs. Thus individuals do not recognize themselves as part of the social context that, for example, the workplace represented for their parents, but feel free to conduct their lives without subordination to any social or political project beyond themselves. The social context that was provided by work, or a dense net of communal relations, is now being replaced by a more personally fabricated structure created through self-projects investing daily activities with meaning. This tendency to privatize the social reveals the spread into the tissue of our personal lives of neo-liberal economic doctrines produced by a globalized world that encourages individual improvement rather than contribution to the community's welfare, with the consequent erosion of the social bond. New Individualism is thus different from previous concepts of individualism because of the central place occupied by globalization, which has undermined traditions, expanded the range of personal choice, and created a privatized culture where people are expected to look for personal solutions to problems which are part of the social rather than the individual. Furthermore, social categories are no longer useful to understand this new world, since nowadays the most visible problems are not social but cultural, as exemplified by the shift in work patterns: the technical revolution has distanced us from the industrial society of the past where work entailed class division. The new information society can reach everyone and therefore does not inevitably produce a social divide. Similarly, current international clashes are no longer indexes of social trouble but of cultural conflict: the 2001 terrorist attack on the World Trade Center, often mentioned as an example, proves the global impact of the cultural clash between Western societies and the Muslim world (Touraine 1-32, 67-69, 208).

3 Accounts of the New Individualism tend to point out its negative consequences: for example, the increase of violence against social norms, the anxiety brought along by compulsory self-creation when individuals are not given guidance as to what is worth pursuing, and the undermining of trust, commitment and long-term relations caused by that demand to constantly reinvent ourselves (Elliot \& Lemert 17-42). However, in 
studies of the phenomenon there appears at the same time a common impetus to emphasize transformative action as a possibility opened by this new state of affairs. Zygmunt Bauman speaks of the need to move from the attitude of the spectator to that of the agent (201-221), and among Alain Touraine's main concerns is the definition of the subject in ways that go beyond the notion of self-reinvention. He elaborates his concept of what he terms "the subject", to him consisting of the individuals' will to struggle for agency by asserting personal rights and opposing the impersonal world of consumption, violence and war. The subject tends to be more present in situations of injustice or attacks on human rights, in which a reaction is needed (101-143).

The main hypothesis of this essay is that the concerns of the New Individualism have created a cultural discourse that pervades contemporary Hollywood film, and that in the articulation of this discourse the conventions of the crime film play a major role. It can be found in such diverse films as Crash (Paul Haggis, 2004), Syriana (Stephen Gaghan, 2005), Lord of War (Andrew Niccol, 2005), Bordertown (Gregory Nava, 2006), Babel (Alejandro González Iñárritu, 2006), The Good Shepherd (Robert de Niro, 2006), or A Mighty Heart (Michael Winterbottom, 2007). Whilst New Individualism makes its way into cinema through an even wider range of generic conventions than those represented by these texts, the focus of the essay will be the crime film, the genre which, critics argue, has traditionally reflected admiration for competitive individualism (Palmer 68). One hypothesis of the paper is that, when articulating the discourse of the New Individualism, the conventions of the crime film are mobilized more often and more intensely than those of any other genre, which would point to the association that Western culture makes between the dangers expressed by crime film representations and contemporary social change. The paper will concentrate on the ways in which crime films articulate the discourse of the New Individualism, and on how this discourse in turn affects the conventions of crime genres. More specifically, the discussion will centre on Silver City (John Sayles, 2004), The Constant Gardener (Fernando Meirelles, 2005), and The Departed (Martin Scorsese, 2006), films which, whilst demonstrating coincidences they are at the same time different, pointing to the wide range of conventions summoned by contemporary cinema in order to express the broad discourse of the New Individualism. Furthermore, the three films occupy a special place within US American popular forms as cultural hybrids, beyond the scope of average Hollywood films. The Constant Gardener is a basically British production incorporated to Hollywood through distribution, and Fernando Meirelles' direction in it is reminiscent of his previous Cidade de deus/City of God (2002), a crime film set in the slums of Rio de Janeiro that suggested the global impact of the issues pointed out by New Individualism theories. John Sayles' film echoes the director's sensibility towards non-US American cultures that he showed in Men with Guns (1997) or Casa de los babys (2003), while Scorsese's aura as one of America's iconic filmmakers is counterbalanced by The Departed, an adaptation of the successful Hong Kong film Infernal Affairs (Andrew Lau, Alan Mak, 2002). These connections with other cultures suggest that the discourse of the New Individualism is a global one. Attention will nevertheless be devoted to the Hollywood crime film and the US American cultural context in order to set the analysis in a delimited territory where manageable conclusions can be drawn.

5 In my consideration of film conventions, I make use of Altman's 'generic maps', a concept implying that films are intrinsically hybrid forms, combinations of structures from several genres. Generic maps change constantly and are thus historically contingent. Individual films incorporate overlapping maps of several genres, reflecting 
the range of generic discourses available at a specific historical moment (Altman 70, 123-143). At its most basic level, the crime film map is a narrative structure that articulates the conflicting relationship between the individual and society-the clash between personal initiative and the community-by tracing the lives of criminals, victims and agents of the law. Following Charles Derry, concentration on each of the three protagonists of crime produces, respectively, the gangster film, the suspense thriller and the detective/cop film (55-69). The views in these texts are expressed through what Deborah Thomas has called, in a different context and for a different purpose, the passage from a social space plagued by fantasies of power and disempowerment-a domestic setting, a community, etc.-to a space of adventure and escape from social oppression-the city's underworld, the wilderness, etc.-through which the characters achieve self-assertion (13). ${ }^{2}$ These two spaces overlap the basic narrative structure of the crime film, since the conflicts between the individual and the social are resolved by breaking free from the strictures of communal life and, usually, by breaking the law. Hence the fascination of these films with the figure of the criminal: victims and agents of the law often become interesting to the audience in as much as they exhibit the personal initiative and capacity for self-assertion attributed to criminals (Leitch 15-16). At those levels of the narrative structure of conflict and the passage from the social space to the space of adventure, action and violence function in order to describe the characters' relation to the group. In this, action and violence voice the contradictory social tendency to control individuals' behaviour while displaying instances of personal initiative that contravene the law and socio-political organization. It is this social ambivalence about personal initiative that the crime film generic map enunciates most powerfully.

Silver City, The Departed and, to a lesser extent, The Constant Gardener, are organized by alternating between several lines of action and characters. From the start, Silver City lays down the structure of a private eye narrative that invites the spectator to accompany Danny (Danny Huston) on his calls to people connected with corrupt governor candidate Dick Pilager (Chris Cooper). This structure still distinguishes Silver City from the more openly textual dynamic of films like Crash, Syriana, or Babel, where the transitions are only justified as the texts' desire to elaborate an argument. This purer textual dynamic is also there, but at the service of action, in The Departed since, after an initial introductory segment, the story moves freely, without scenes being ushered in by any character, between infiltrated cop Costigan's (Leonardo DiCaprio) activity as one of Costello's (Jack Nicholson) gangsters, Queenan's (Martin Sheen) offices, and infiltrated mobster Sullivan's (Matt Damon) manoeuvres. The text is thus closer than Silver City to the action film and the alternation between several spaces closer to its function as pure creator of suspense.

7 Under the influence of the New Individualism discourse about the connectedness of contemporary societies, the suspense mechanism of crosscutting is boosted to an unprecedented degree by accommodating not only simultaneous actions but also interrelated stories, locales and characters. The cultural discourse that views the world as a network has transformed the conventions of the crime film generic map by widening the range of interactions typical of the classical forms of the genre. It is articulated by alternating between several lines of action that evolve in various settings, although not necessarily in a simultaneous way, which suggests similarities and contrasts in terms of the characters' class and ideological stance. In doing this, films often borrow the multiple-protagonist structure, which has been closely analysed 
by recent research: Charles Ramírez Berg has provided an exhaustive taxonomy of the phenomenon, Huan L. Hsu has discussed the nature of ensemble films set in Los Angeles, and $\mathrm{M}^{\mathrm{a}}$ del Mar Azcona-Montoliú has contributed a theory that sees multipleprotagonist films as already an established genre. Both Hsu and Azcona-Montoliú point out how these films share such formal and stylistic elements as crosscutting, constant camera movement and continuity editing in order to connect discontinuous spaces and different narrative lines (Hsu 134-137, Azcona-Montoliú 123-174). The resulting texts imply that all these stories are linked by a common thread supporting one central argument, and that individual decisions do have consequences for the lives of others since everybody and everything is interconnected in today's world.

8 Paradoxically, in the three films this heightened crosscutting also portrays the characters as isolated individuals, inexorably bound to face a world so large that they lack the necessary perspective to understand their role in it; and in this, crosscutting is aided by framing. In The Constant Gardener handheld camera movements express the anxiety of the characters or the excitement of the bustling streets of Kibera (49'), a visual texture that recalls the mix of documentary and MTV style of Meirelles' previous Cidade de deus. Justin Quayle's (Ralph Fiennes) visit to Berlin on his search for information about dypraxa, the drug illegally tested in Kenya, displays frantic handheld camera movements, fast editing, and close shots that echo the danger he and his informants believe to be in during their meetings $\left(75^{\prime}-81^{\prime}\right)$. Scorsese's visual style in The Departed is clearly an auteur signature, but the elaborate camera movements for which Scorsese is known also convey an atmosphere of uncertainty that prompts characters to move constantly if they want to stay alive; for example while Costigan chases Sullivan after the infiltrated gangster has met his boss Costello at a porn cinema $\left(84^{\prime}-86^{\prime}\right)$ Silver City's frame movements are more in tune with the independent-feature aesthetic characteristic of Sayles' cinema, but again their effect is to reinforce Danny's rambling investigation and create the feeling that most of the times he is out of his depth, as when he crashes into one of the Pilagers' fund-raising parties (56'-63'). In the three films, camera movement combines with a close framing distance which, while suggesting access to the subjectivity of the protagonists, in fact constructs characters who possess only a partial knowledge of the reality they inhabit. Thus, the impression is that much more is left offscreen than we actually see, that onscreen space is limited and limiting and that we, like the characters, can only see a small portion of the whole picture. These stylistic choices are actually part of a widespread form of contemporary Hollywood cinema which David Bordwell has termed "intensified continuity" (121-138), and which in the films object of analysis here voices social anxieties. In the context of the crime film, this is an emphatic version of the subjectivity and impaired knowledge that defined classic crime film heroes, especially those of noir, and which has come to define the visual style of the New Individualism crime film generic map.

More generally, it is the conventions of the crime film that articulate social trouble in these films, and among them stands out the use of specific unlawful activity as catalyst for the representation of social concerns. It is through the death of Lázaro Huerta in Silver City, murder and gang life in The Departed, and illegal pharmaceutical experimentation in The Constant Gardener that social conflicts come to the surface and become discourses in the films, even literally in the case of Silver City since the body of illegal worker Lázaro, found floating in the lake, becomes a leitmotif in the story (4'). Unlike previous crime films, where the social tended to be a subtext hinted at by criminal activity, they centre on the social dimension of the characters' problems. Silver 
City exposes the exploitation of illegal immigrants and the control of politics by corporate interests, The Constant Gardener denounces state complicity with the greed of pharmaceutical companies, and even The Departed, the seemingly most generic of the three films, is as much about action and suspense as about the complex relation of individuals to the group. The New Individualism discourse leads the crime film generic map in these texts to address social issues more openly than was the norm in classical crime movies. Although cinema has always displayed social conflict through the individualizing agency of characters, these films lay special emphasis on the social origin of these problems.

However, these texts at the same time show the changing nature of conflicts. Thus, in The Constant Gardener Justin Quayle's initial reluctance to get involved in the realities of Kenya is caused by his cultural distance from it. While Tessa (Rachel Weisz) strives to adapt to the country's culture, Quayle keeps alive his fantasy of an English garden in the middle of a politically conflicted land (31'). The film suggests that this kind of cultural isolation has paved the way for the questionable collaboration of the British embassy with pharmaceutical companies. Similarly, Danny's investigation in Silver City only advances when he hires Tony Guerra (Sal Lopez) to look into the connections between workhand baron Vince Esparza (Luis Saguar) and Bentel, the corporation protected by the Pilagers ( $\left.60^{\prime}\right)$. Tony can help him because, like Esparza and most illegal immigrants in Colorado, he is Chicano and does not arouse the suspicions among labourers that Anglos do. Despite their physical proximity, Danny's cultural distance from those men is insurmountable, and the film suggests that this distance is at the core of the trouble behind Bentel because its owner, Wes Benteen (Kris Kristofferson), and the Pilagers take the suffering of their labourers for granted. The growing visibility of cultural conflict is expressed through representations of animosity and anger that grant textual prominence to cultural barriers, while emphasis is placed on the lethal consequences of the incommunication caused by cultural difference. The conventions of the crime film generic map are thus appropriated and transformed in order to show how the causes of conflict are not only corrupt politicians and corporate greed but also cultural difference, while the choice of these conventions by contemporary cinema hints at the link that Western societies see between cultural diversity and social unrest today.

11 This bleak view of present-day life is most vividly expressed by the films' powerful representations of passivity and victimhood. In The Departed Costigan embodies this helplessness of the victim when he is incapable of living up to the standard set by Costello. As the gang leader says in the opening scene, his philosophy of life asserts people's command of their world: "I don't want to be a product of my environment. I want my environment to be a product of me", he yells (40"). However, Costigan cannot do so but has to seek psychiatric help and finally resort to sedatives in order to endure his life as an infiltrated cop (49'). By focusing on Costigan's difficulties to cope, and by integrating them within a romantic relationship with Madolyn (Vera Farmiga), the psychiatrist, the film transforms his problems into a personal affair, presenting his anxiety as the consequence of an inherent moral goodness that makes him unfit to live a double life. The origin of his difficulties is to be found in the heterogeneous nature of contemporary society, which demands that individuals adopt different identities simultaneously in order to match the several contexts in which they operate in their everyday lives; they are thus expected to have as many identities as people and circumstances they relate to (Elliot \& Lemert 36). This produces alienated individuals 
forced to be "someone else" all the time in order to adapt to such diversity. Costigan complains about this to Queenan, arguing that he cannot be someone else every day, to which Dignam (Mark Wahlberg) replies that it is no big deal because most people do it all the time. Through Madolyn, the film also points to lack of trust and commitment as the cause of Costigan's anxiety, since their meetings are always pervaded by doubts about the sincerity of the other's attitude ( $\left.78^{\prime}\right)$. Costigan embodies the negative effect of being asked to reinvent himself constantly, with the consequent erosion of his capacity to trust others and commit himself.

In these New Individualism crime films the melodramatic centrality of the victim articulates the narratives' fluctuation between emphasis on the social/cultural origin of problems mentioned above and attention to the helplessness of the protagonists: the personal initiative of the protagonists of crime disappears as melodrama takes over, at times leaving social problems aside and concentrating instead on the incapacity of the individual to face them. The films voice this concern with the unbearable weight laid on the shoulders of individuals by first borrowing conventions of the suspense thriller and then having them overlapped, even at times replaced, by those of melodrama. For Charles Derry, the suspense thriller deals with the process through which innocent victims are threatened until they finally muster enough courage to oppose aggression with their own dose of violence (3-69). Its protagonists are thus active victims, characters who combine helplessness with initiative. In Silver City, The Constant Gardener and The Departed the main characters are presented as potentially active, occasionally enraged, and at times even as criminals themselves, but the stories always end up emphasizing their status as victims and their impotence; they match the victim heroes and heroines that have traditionally populated the classical notion of melodrama (Heilman, in Walker 2-3). At this point, the generic map of classical melodrama overlaps, and finally takes over, the map of the suspense thriller.

13 This is the same helplessness of individuals in the face of social problems that led Ulrich Beck to remark that our lives have become the "biographical solution of systemic contradictions" (137), as citizens are expected to provide individual, personal answers to the problems of societies. The possibility that the social organizations themselves may be of the wrong kind is not even considered, and the whole responsibility for their present state is laid at the door of individuals (Bauman 166-170). Despite their different nature, both social and cultural problems share the consideration that the New Individualism grants them as structural, systemic trouble to be solved not in the public sphere but in the private one, thus extending the neoliberal economic doctrine of privatization to the realm of the personal.

Living in a world which cannot be known or controlled produces an inevitable hostility towards social norm, towards the laws that societies dictate in order to regulate communal life and supposedly preserve the rights of individuals, but which do not actually function as such guarantee of personal welfare. The crime film has traditionally articulated this hostility in the form of ambivalence towards the law through stories that entertain breaking the norm only to finally abide by it, and it is thus no surprise that contemporary cultural forms borrow its conventions to express an anxiety that dates back to the classic gangster films of the 1930s. Thomas Leitch has updated this cultural analysis by defining the several film genres of crime according to their capacity to voice this ambivalence. To him, the field of the crime film is characterized by a complex interplay between ideologies that exhibit divergent 
attitudes towards social norm. It works by first setting clear-cut positions vis-à-vis the law-held by criminals, avengers or victims-only to quickly trace the characters' change as they approach positions which had initially been presented as antithetical. Cops/detectives tend to break the law while victims embrace violence, both thus becoming criminals, and gangsters are often revealed to be victims of their lifestyle: it is these shifts that make of ambiguity towards social norm the trademark of the genre (306). Traffic (Steven Soderbergh, 2000) represents to Leitch the paradigmatic crime film for its capacity to make characters swerve from one allocated position to another initially represented by a parallel story, a dynamic that also organizes Silver City, The Departed and The Constant Gardener. Danny's charm is largely due to the fact that he embodies both the authority of the private eye and the victim look of someone fond of confronting forces he lacks the power to beat. The appeal of both Sullivan and Costigan lies in their combination of mobster and cop, and Quayle evolves from bystander to avenger after Tessa's murder, and then to victim as he asks to be left alone and await a certain death in lake Turkana (113').

15 The New Individualism crime films' explicit presentation of a fluidity that usually informs the genres of crime, but to which these have rarely directed the viewers' attention, has three effects. Firstly, it points to the centrality of crime as textual motif in contemporary Hollywood representation, which actually suggests the pertinence of the instability evoked by crime to Hollywood's perception of contemporary Western societies. Secondly, it indirectly confirms the validity of the broad generic notion of the crime film as an alternative to the discrete genres of the gangster film, the cop/ detective movie and the suspense thriller. And thirdly, it points to New Individualism crime texts as representative forms of a new stage of the crime film in which those discrete genres self-consciously reach a syncretism that finally overcomes their division. Thus one may conclude that never before today has the generic map of the crime film so perfectly matched the discourse about the social ambiguity towards the law, whose cultural currency points to the pervasive nature of that ambiguity at the present time.

16 Furthermore, the New Individualism crime films extend it to the social and its institutions. The Departed directs this widespread ambiguity towards the Massachusetts State Police and, by extension, towards political institutions symbolized by the gilded dome of Boston's State House. The dome's view that infiltrated mobster Sullivan enjoys from his luxurious apartment proves that his aim is higher than the police: he has learned to bend the rules and hopes the prize will be a job in politics (16'). Infiltrated cop Costigan, however, chooses to play by the rules to devastating consequences, as he finds himself outside the protection of the police. He faces a world where the institutions that forged him do not actually support those who choose the right path. This time, vulnerability is caused by the lack of the very same social net that should presumably reassure the individual in the event of a fall, a lack that increasingly defines contemporary life (Touraine 67-69). According to Foster Hirsch, this distrust of institutionalized authority has been typically adopted by the contemporary crime film, and Prizzi's Honor (John Huston, 1985), Miller's Crossing (Joen \& Ethan Coen, 1990) or The Godfather, Part III (Francis Ford Coppola, 1990) already have the police, the mayor and even the Vatican entangled with the mob (354-355). New Individualism crime films are, however, different from the examples mentioned by Hirsch because of both the centrality acquired by melodrama and the explicit presentation of the social origin of trouble. Their emphasis is on the characters' despair at a situation which they 
experience as completely disempowering, and on their awareness that, despite the difficulties, they are expected to remain loyal to the social, no matter how damaging it may be. Characters are thus seen to long for a social structure that they need in order to conquer a true autonomy and capacity for self-assertion, they find out that such a structure is missing but keep on struggling.

The centrality of victimhood in these films reflects a renewed concern with ethical action, probably best illustrated by the ethical demands that abound in Silver City and The Constant Gardener. Danny O'Brien faces the surrender of almost every new person he encounters to the reality principle summed up by Chandler (Billy Zane), Nora's lobbyist boyfriend: "power is a locomotive, babe, you either hop on board or it runs right over you" $\left(45^{\prime}\right)$. Despite this, he keeps inquiring into the dark secrets of the Pilagers, propelled by what in that world seems an old-fashioned, useless loyalty to truth and decency. Similarly, Quayle pursues the clues left by Tessa about KDH and ThreeBees, the two companies involved in the illegal ТВ tests, by travelling to London and Berlin after he realizes the plot to make him believe that she was killed by Arnold Bluhm (Hubert Koundé). Even in The Departed, a far more cynical film, we find Queenan's demand that Costigan behave ethically, by overcoming the anxiety of his undercover life, and keep on the job of exposing Costello's activities (54').

The films' climactic moments have characters realize this need for ethical action in the face of utter injustice or oppression, and ethical epiphanies often become the films' central set-pieces, emphasized by musical themes that create the mood of the New Individualism film. One such epiphany appears in The Constant Gardener through a combination of Alberto Iglesias' music with fast editing that portrays Quayle's return to Kibera, during which he discovers ThreeBees' manoeuvres with the poor population of the ghetto. Music is also central to the representation of the characters' defeat after having reacted against injustice. Quayle is finally killed while the corrupt British diplomacy and the pharmaceutical companies stay in their place: he is aware that he should act against them, but also that the venture is doomed. Thus he just commits suicide by travelling to the remote spot where his wife was killed and awaiting a certain death while a string composition, also by Iglesias, sounds over images of his hallucinations, in which he talks to Tessa, and the approaching bandits (113'). The scene is crosscut with Ham's (Richard McCabe) denunciation that Pellegrin (Bill Nighy), head of the Foreign Office, had given orders to intimidate Tessa, which takes place later in the story, at Quayle's funeral back in England. This convention is more frequently and obviously used by such New Individualism films as Crash, Syriana or Babel, where the set-pieces tend to establish the tone of the narratives.

19 In all these cases the incapacity to act stems from the absence of support for the characters. Danny meets political or economic ambition and Quayle the greed of pharmaceutical companies when they try to act, while their limited accomplishments cannot dispel the atmosphere of desolation left by the lack of a solid structure that should guarantee human rights and reward ethical decisions. Still, ethical action appears as the only method of social transformation, a point similarly made by Alain Touraine through his notion of "the subject", that is the individual's will to master the course of one's life by vindicating one's rights and opposing consumption, violence and war. Touraine sees in this recuperation of individuals' agency over their lives and circumstances the only possibility for contemporary societies to escape the yoke of supranational structures of oppression such as globalized markets and politics 
(101-143). However, this hope is tinged with pessimism in the New Individualism crime films, where the task of saving the social through individual action is considered a utopian venture.

The vulnerability of the individual in a complex world which hinders self-assertion was already present in films like the Mexican Amores perros (Alejandro González Iñárritu, 2000), which proves that this concern is a consequence of globalized societies at least in the last decade. Later appeared such crime films as Silver City, The Constant Gardener or The Departed, where melodrama, combined with the need for an ethical impulse, remains deeply ingrained in the narratives. These films show the lack of what Touraine calls "the subject", the difficulty of defending one's rights against injustice in a contemporary world that destroys our capacity for action. This view of the absent subject, coupled with the expression of the need for ethical behaviour, attests to the influence of the post 9/11 climate in the Western world, a mix of impotence and ethical revival that characterizes these first years of the $21^{\text {st }}$ century. The New Individualism crime films have seen the melodramatic ingredient intrinsic to the crime genres boosted by the influence of this renewed ethical discourse, whose imprint is found in all the New Individualism film narratives. Like the films discussed above, texts such as Crash, Syriana, Lord of War, Bordertown, Babel, The Good Shepherd or A Mighty Heart borrow the conventions of the crime film and melodrama generic maps to different degrees in order to articulate social and cultural unrest.

While the Hollywood crime film has always provided views of self-assertion, contemporary crime films increasingly show impotent human beings, overwhelmed by problems which, despite having a social origin, they are asked to face and solve individually. This has made the suspense thriller and melodrama very relevant genres because they construct characters as victims; and Silver City, The Constant Gardener and The Departed show their impact by producing helpless creatures engulfed by criminal conspiracies. However, while in the suspense thriller the individual vindicates himself/ herself through heroic action, in New Individualism films this action, although still potentially heroic, triggers ethical dilemmas instead. As melodrama steps in, the films reveal the anxiety of individuals who feel action as an ethical obligation while at the same time have to face their own impotence under the pressure of social or global problems.

The traditional crime film discourse that self-assertion is to be gained through escape from the social is given a twist by these texts, where it adopts the form of an ethical impulse instead. Even escape itself is considered impossible since definitions of the self are represented as dependent on its relations to others. Assertion of the self cannot be achieved without the presence of others and ethical intervention in relation to them, which makes escape from society not the liberating move it was in traditional crime films. In these new texts, individuals lack any space that they can escape to, they act but cannot avoid the forces that oppress them, try to run away but find themselves back where they were. This representation points to the appearance of a new cultural discourse originated by changes in a social space immersed in a process of dissolution as the structures of belonging to groups or communities gradually disappear. Instead, there is only the self against the forces of national and global economies, and against the cultural fights that begin to replace traditional social struggles. These films introduce the need to escape only to then show that there is nowhere to escape to because there is no longer any difference between the space of the social and the space 
of adventure: the qualities that had always been attributed to adventure have come to define the void opened by the dissolution of the social fabric, which has been replaced by incoherence, risk, and lack of trust or commitment. The allure of adventure vanishes too, as in this new discourse it turns out to be ruthless and grim rather than glamorous or liberating.

Even this conceptualization in terms of spaces reveals itself dated: whereas the utopias of modernism were basically anchored in space, that is, they located the desired state of affairs in a specific place, be it the city on a hill or Walden, the dreams of this new society are dreams about keeping on the move. Instead of being anchored in a stable space, they have to do with speed and acceleration (Bauman 222-241), precisely what these new films constantly provide: fast movement from one action to another and crosscutting elevated to the category of narrative principle. It is thus no surprise that the last third of The Departed, in which one by one killers turn into victims of somebody above themselves in the game of deception, shows an increasingly fast pace that is probably most in tune with the feel of contemporary life, where ambivalence, uncertainty and vulnerability prevail. Where once Boston's State House stood for the solid hopes of a country, we now only find a frantic movement forward into contemporary dystopia.

\section{BIBLIOGRAPHY}

Altman, Rick. Film/Genre. London: BFI, 1999.

Azcona-Montoliú, Ma del Mar. All Together Now: The Rise of U.S. Multi-Protagonist Films in the 1990s. Ph. D. dissertation, Universidad de Zaragoza, 2007.

Bauman, Zygmunt. Society under Siege. Cambridge and Malden MA: Polity Press, 2002.

Beck, Ulrich. Risk Society: Towards a New Modernity. Trans. Mark Ritter. Los Angeles, London: Sage, 2007 (1986).

Berg, Charles Ramírez. "A Taxonomy of Alternative Plots in Recent Films: Classifying the 'Tarantino Effect.'" Film Criticism XXXI, 1-2, Fall/Winter (2006): 5-61.

Bordwell, David. The Way Hollywood Tells It: Story and Style in Modern Movies. Berkeley and London: U of California P, 2006.

Clarens, Carlos. Crime Movies: An Illustrated History of the Gangster Genre from D.W. Griffith to Pulp Fiction. Updated by Foster Hirsch, Cambridge MA: Da Capo Press, 1997 (1980).

Derry, Charles. The Suspense Thriller: Films in the Shadow of Alfred Hitchcock. Jefferson, NC and London: McFarland, 1988.

Elliot, Anthony and Charles Lemert. The New Individualism: The Emotional Costs of Globalization. London and New York: Routledge, 2006.

Hirsch, Foster. "Afterword." In Carlos Clarens. Crime Movies: An Illustrated History of the Gangster Genre from D.W. Griffith to Pulp Fiction. Cambridge MA: Da Capo Press, 1997 (1980). 339-360. 
Heilman, Robert. Tragedy and Melodrama: Versions of Experience. Seattle: U of Washington P, 1968.

Hsu, Hsuan L. "Racial Privacy, the L.A. Ensemble Film, and Paul Haggis's Crash." Film Criticism XXXI, 1-2, Fall/Winter (2006): 132-156.

Leitch, Thomas. Crime Films. Cambridge, New York: Cambridge UP, 2002.

Munby, Jonathan. Public Enemies, Public Heroes: Screening the Gangster from Little Caesar to Touch of Evil. Chicago and London: The U of Chicago P, 1999.

Palmer, Jerry. Thrillers: Genesis and Structure of a Popular Genre. New York: St. Martin's Press, 1979.

Rafter, Nicole. Shots in the Mirror: Crime Films and Society. New York: Oxford UP, 2000.

Rubin, Martin. Thrillers. Cambridge: Cambridge UP, 1999.

Shadoian, Jack. Dreams and Dead Ends: The American Gangster Film. 2nd edition, New York: Oxford UP, 2003.

Telotte, J.P. Voices in the Dark: The Narrative Patterns of Film Noir. Urbana: U of Illinois Press, 1989.

Thomas, Deborah. Beyond Genre: Melodrama, Comedy and Romance in Hollywood Films. Moffat:

Cameron \& Hollis, 2000.

Touraine, Alain. A New Paradigm for Understanding Today's World. Trans. Gregory Elliott, Cambridge and Malden MA: Polity, 2007 (2005).

Walker, Michael. "Melodrama and the American Cinema." Movie 29/30, Summer (1982): 2-38.

Warshow, Robert. "The Gangster as Tragic Hero." The Immediate Experience. Cambridge, MA: Harvard UP, 2001 (1948). 97-103.

\section{NOTES}

1. Research towards this article has been funded by the DGI project no.

HUM2007-61183. I would also like to thank Celestino Deleyto and the anonymous referees of EJAS for their comments on earlier drafts.

2. Thomas uses these terms to define her notion of the melodramatic mode, which to her covers, together with the modes of the comedy and romance, all the genres of Hollywood cinema.

\section{ABSTRACTS}

This article focuses on contemporary Hollywood films Silver City (2004), The Constant Gardener (2005) and The Departed (2006) in order to examine the intersection of the cultural discourse of the New Individualism, characterized by the helplessness and anxiety of the subject in the face of social change, with the generic conventions of the crime film. It explores the ways in which such conventions as crosscutting and suspense, the victim-hero of the thriller, or the trope of selfassertion through escape from the social space both articulate the New Individualism discourse and are transformed under its influence. 
INDEX

Keywords: Crime film, New Individualism, thriller, melodrama, Alain Touraine, Zygmunt Bauman, John Sayles, Fernando Meirelles, Martin Scorsese

\section{AUTHOR}

\section{LUIS M. GARCÍA-MAINAR}

Luis M. García-Mainar, Universidad de Zaragoza (Spain) 